\title{
Thermal conditions and age structure determine the spawning regularities and condition of Baltic herring (Clupea harengus membras) in the NE of the Baltic Sea
}

\author{
Timo Arula ${ }^{\text {Corresp., } 1}$, Heli Shpilev ${ }^{1}$, Tiit Raid ${ }^{1}$, Elor Sepp \\ ${ }^{1}$ University of Tartu, Estonian Marine Institute, Tallinn, Estonia \\ Corresponding Author: Timo Arula \\ Email address: Timo.Arula@ut.ee
}

Baltic herring (Clupea harengus membras) is a total spawner with a group-synchronous ovarian organization. Age polymodality in total spawners is considered an important factor in assuring that a strong population is sustainable under an intensive harvesting regime and different climatic conditions. In the present study, we investigated the seasonal and inter-annual variation in spawner age structure and the effect of preceding winter thermal conditions on the start of the herring spawning and larvae retention period. Herring spawning season in the Gulf of Riga starts up to six weeks later after colder winters compared to milder winters. Significantly older individuals dominated at the beginning of the spawning season, and thus herring mean age gradually decreased towards the end of the spawning season from 1999-2015. On an annual scale, this pattern was obvious after cold winters, while after mild winters the pattern did not continue, indicating a more homogenous maturation cycle and spawning period, despite the age and size of the herring population in mild winters. Further, herring condition factor was studied in relation to age and spawning season following different winter thermal conditions. Young, 2- and 3year old first-spawning herring experienced significantly lower conditions after cold winters compared to older ages, indicating an age-dependent effect of preceding winter on herring maturation cycle, condition and spawning time. 
1 Thermal conditions and age structure determine the spawning regularities and condition of Baltic

2 herring (Clupea harengus membras) in the NE of the Baltic Sea

3

4

5

6

7 8

9 Corresponding Author:

10 Timo Arula

11

12

13

14

15

16

17

18

19

20

21

22

23

24

25

26

27

28

29

30

31

32

33

\section{Abstract} condition and spawning time.

Timo Arula, Heli Sphilev, Tiit Raid, Elor Sepp

Estonian Marine Institute, University of Tartu, Mäealuse 14, 12618 Tallinn, Estonia

Estonian Marine Institute, University of Tartu, Mäealuse 14, 12618 Tallinn, Estonia

Email address: timo.arula@ut.ee

Baltic herring (Clupea harengus membras) is a total spawner with a group-synchronous ovarian organization. Age polymodality in total spawners is considered an important factor in assuring that a strong population is sustainable under an intensive harvesting regime and different climatic conditions. In the present study, we investigated the seasonal and inter-annual variation in spawner age structure and the effect of preceding winter thermal conditions on the start of the herring spawning and larvae retention period. Herring spawning season in the Gulf of Riga starts up to six weeks later after colder winters compared to milder winters. Significantly older individuals dominated at the beginning of the spawning season, and thus herring mean age gradually decreased towards the end of the spawning season from 1999-2015. On an annual scale, this pattern was obvious after cold winters, while after mild winters the pattern did not continue, indicating a more homogenous maturation cycle and spawning period, despite the age and size of the herring population in mild winters. Further, herring condition factor was studied in relation to age and spawning season following different winter thermal conditions. Young, 2- and 3- year old firstspawning herring experienced significantly lower conditions after cold winters compared to older ages, indicating an age-dependent effect of preceding winter on herring maturation cycle, 


\section{Introduction}

35 Age structure of spawning populations, spawning seasonality, and migration to spawning grounds

36 have been widely studied in relation to fishing regulations for population conservation and climate 37 variability (Lambert, 1987; Sims et al., 2004; Sissener and Bjørndal, 2005; Margonski et al., 2010).

38 A fish population that is sustainable in the long run contains a wide diversity of age classes within 39 the limits of species-specific life span (Planque et al., 2010; Brunel and Piet, 2013). For Baltic 40 spring spawning herring (Clupea harengus membras), there have been no studies focusing on the 41 age structure of spawning population, although such material has been collected with high 42 precision for decades for routine stock assessment (ICES, 2018). Within the same spawning 43 season, many different spawning groups of herring exploit same spawning ground, migrating to 44 spawning grounds in "spawning waves". Predictions of such spawning waves provide resource managers grounds to plan commercial fishing to conserve certain age classes (Sissener and Bjørndal, 2005). Age-specific spawning waves would appear to be the result of differential maturation with older, returning individuals spawning first, and younger, first time spawning groups progressively later (Rannak, 1971; Ojaveer et al., 2004; Raid et al., 2010). Still, fish spawning regularities vary between years and are hardly predictable based exclusively on age structure (Sims et al., 2004; Sissener and Bjørndal, 2005). Fish tend to have certain adaptation plasticity in the timing of life cycle events such as reproduction and in the length of spawning seasons as a response to environmental cues (e.g. photoperiod and temperature, Geffen, 2009). energy allocations which determine individual condition (Lambert and Messieh, 1989; Slotte et al., 2000). However, such patterns may be modified by annually varying hydro-climatic conditions interacting with feeding conditions in overwintering areas, a mechanism that remains poorly studied (Kjesbu, 1994). Thus, the spawning regularities of age classes dominating in a mature component of the fish stock occur in "spawning waves" (Lambert, 1990). Such a spawning pattern is believed to be an effective tactic to secure higher survival probability for the first-feeding larval stage because they are distributing their hatching over a longer period of time (Secor, 2000). To analyze and understand this pattern accepts complex studies that include detailed observation data of spawning populations and the surrounding environment - material that may not exist for some commercially harvested fish populations (Secor, 2015). Based on long-term observations it has been demonstrated that in years when the spawning season was of longer duration, more abundant 
65

66

67

68

69

70

71

72

73

74

75

76

77

78

79

80

81

82

83

84

85

86

87

88

89

90

91

92

93

94

95

year-classes of herring were produced (Dragesund, 1970; Ojaveer et al., 2011). The habit of herring spawning over a longer period leading to a succession of larval cohorts is a bet-hedging tactic which enhances the probability to match larvae in space and time with a highly variable prey field (Lambert and Ware, 1984). Thus, a higher number of spawning waves/larval cohorts over time should secure a more abundant year-class.

Baltic herring contributes, an average of $42 \%$ of commercial fishery in the Baltic Sea (Raid et al., 2015). Total landings of herring in the Baltic Sea have stabilized during recent years to around 200-250 Kt after being under $200 \mathrm{Kt}$ in 2004-2005 (Raid et al., 2015). Baltic herring spawn in coastal areas, where high food and oxygen concentrations create a good environment for successful hatching and ontogeny of larvae (Raid 1985; Arula et al., 2012, 2015, 2016). After spawning in late spring and early summer, adults migrate to deeper waters to feed and improve their fitness before winter (Ojaveer et al., 2003). The coastal areas (especially Pärnu Bay) in the NE of the Gulf of Riga (GoR) serve as a suitable spawning environment for the GoR herring population, with the adjacent coastal areas being the most intensely utilized spawning and nursery grounds (Ojaveer et al., 2011).

The GoR herring spawns from mid-May to mid-July at temperatures from 9 to 16 degrees C, mainly on demersal vegetation, gravel, etc. The depth of the main spawning grounds varies from 2 to $5 \mathrm{~m}$. Spawning of the GoR herring is temporally separated from its neighboring populationthe open-sea herring of the NE Baltic, belonging to the Central Baltic herring stock. Central Baltic herring population spawns earlier around the Saaremaa and Hiiumaa islands (from the middle of April to the middle of June) and at a lower temperature (5-13 degrees C) than the GoR herring. However, some overlapping occurs because part of the Central Baltic herring population spawns in the eastern areas of the gulf, including Pärnu Bay (Ojaveer, 1988).

Winter (January-March) air temperatures in the NE part of the GoR have increased from an average of -14.6 degrees $C$ in the late 1940s to -8.6 degrees $C$ in the late 1980s (Ojaveer et al., 2011; Arula et al., 2014a). Cold winters, dominated by easterly winds, are unfavorable for Baltic herring feeding and gonadal maturation. Cold temperatures affect the accumulation of energy before herring reproduction because herring do not feed at temperatures below 2 degrees $\mathrm{C}$ (Ojaveer et al., 2011 and references therein). The maturation and timing of copepod production peak, the major food source of herring larvae, is also hindered by winter temperatures (Arula et al., 2014b). These circumstances motivated us to compare data collected in the GoR spring herring 
96 spawning season from April to July and larval herring retention from May to August in 1947-1986

97 and 1999-2015 and to specifically ask: (i) has the start of spawning season shifted significantly

98 earlier in parallel with warming since the late 1980s; (ii) is the start of spawning season determined

99 by the preceding winter air temperatures and population age structure; (iii) does variation in

100 thermal conditions and spawning time result in different individual conditions between first- and 101 repeat spawners?

102

\section{Materials \& Methods}

104 Structure of spawning schools

105 Individual herrings considered in analyses were regularly collected from commercial trap-net 106 landings stationed on herring spawning grounds or in adjacent areas during the fishing period from 107 April to June (corresponding to calendar weeks 15-25) from 1999-2015 (Table 1). Total length, 108 total weight, age and maturity stage were determined from 12,148 individuals in total (including 109 recruitment, age 1 abundance; Appendix 1). Gender and maturation stage were determined using methods developed by the Workshop on Sexual Maturity Staging of Herring and Sprat Working Group (ICES 2011). The scale includes six maturity stages: (I) immature; (II) maturing; (III) spawning; (IV) spent; (V) regeneration; and (VI) abnormal. The samples analyzed in the present study contained individuals in the pre-spawning and spawning stages (hereafter: spawning) that are ready to spawn.

115 The start of herring spawning season was calculated based on data collected in herring trap-net landings with a weekly accuracy. The start of herring spawning season (hereafter: start of spawning) was determined by the appearance of individuals in the spawning stage found in spring commercial catches. Because Baltic herring spawning season starts shortly after the ice break in Pärnu Bay and herring do not spawn under ice, any spawning earlier than observed in the present study could not occur. National regulations determine the annual allowable catch (quotas) for spawning herring trapnet landings, and therefore competition between herring fishermen exists during trapnet catch season. Herring fishermen landings are restricted with total allowable quotas given each year, based on herring spawning stock biomass. Therefore, fishermen targeting herring spawning schools start shortly after the ice break and always before abundant herring spawning 125 schools migrate to Pärnu Bay. Trapnets are regularly inspected by fishermen in that period and, 
126 due to regular fisheries monitoring obligatory fish research, communication regarding 127 presence/absence of spawning herring in trapnets is available for researchers.

128 In order to compare the start of spawning season in Pärnu Bay before and after 1990, the number 129 of years that were available in each decade were used: 1947-49, 1953-1955, 1964-66, 1974-76, 130 and 1984-86 (for details see Ojaveer et al., 2007). Since the late 1980s, the winter air temperature 131 increased substantially compared to former periods and this has markedly changed the spawning 132 stock biomass, recruitment and larval herring dynamics in the GoR (Ojaveer et al., 2011; Arula et 133 al., 2014a). As we aimed to analyse whether the start of spawning season was significantly 134 different before and after the climate driven regime shift in the late 1980s, and because a limited 135 selection of years prior to the 1990s are covered by data (which may not represent "the average" 136 conditions for each decade), "winter air temperature" and "YEAR" were included as covariates. 137 Therefore, prior to comparing the start of spawning season before and after the 1990s, the 138 homogeneity of slopes for categorical variables for both periods were controlled and compared to 139 achieve adjusted mean cw for the start of the spawning season. Analysis of covariance (ANCOVA) 140 was applied to test the main and interactive effects of categorical variables (winter air temperature 141 and YEAR) on a continuous dependent variable (start of spawning, cw), controlling for the effects

142 of selected continuous variables, which co-vary with the dependent.

144 Herring larvae

145 Herring larvae were obtained at nine stations with a depth ranging from 3 to $10 \mathrm{~m}$ from early May 146 to late August, depending on larval occurrence, covering the same area where spawning herring 147 samples were collected. Hauls were performed with the Hensen larval fish net (mouth opening d $148=80 \mathrm{~cm}$, mesh size $=500 \mu \mathrm{m}$, and codend $=300 \mu \mathrm{m})$ from the near-surface layer $(0-1 \mathrm{~m})$ 149 horizontally by 10-minute hauls at a speed of approx. 2 knots and the volume of water filtered 150 during each haul (measured with flowmeter Hydro-Bios “Digital Flowmeter 483110”).

151 Data for the first appearance and the end of the larval herring occurrences were calculated 152 according to methodology described in Arula et al., 2014a (Appendix 2). These were calculated 153 from the cumulative sums of weekly abundances, with the points reaching $10 \%$ and $90 \%$ from 154 the annual sum, respectively, from 1999-2015 (for details see Arula et al., 2014a). The length of 155 the larval herring occurrence period was defined as the number of weeks from the first appearance 156 to the end of the season (for details see Arula et al., 2014a). The end of herring spawning season 
157 was determined as the previous calendar week of the last abundant presence of recently hatched 158 yolk-sac (S1 6-7 mm) herring larvae. Since water temperatures had increased above 17 degrees C, 159 embryonal development (fertilization of eggs to hatching the yolk-sac larvae) took approximately 160 one week (Ojaveer 1981).

161

162

163

164

165

166

167

168

169

170

171

172

173

174

175

176

177

178

179

180

181

182

183

184

185

186

187

Environmental data

Water temperatures of herring spawning grounds have been quoted as the main characteristic determining successful development of viable embryos and survival of larvae at hatch (Ojaveer, 1981). Data from weekly measurements during larval fish surveys were obtained to characterize suitable temperature conditions for embryonic development and survival. The percentage of hatched normal larvae of spring spawning herring in the GoR depended on water temperature. According to E. Ojaveer (1981), the optimal water temperature of spawning grounds that assure normal embryonal development is between 7 degrees $\mathrm{C}$ and 17 degrees $\mathrm{C}$ for the Gulf of Riga herring. In temperatures above 17 degrees $\mathrm{C}$, embryonal mortality of spring spawning herring was $35 \%$ and increased at higher temperatures.

The sum of monthly mean air temperature (hereafter - winter air temperature) at Pärnu weather station (Fig. 1) in the period of January-March was used as background information. In the shallow Gulf of Riga, the effect of winter severity on thermal regime of the vertical water column is very variable. In the severe winters (presented in our study as $75 \%$ percentiles) the whole sea surface is covered by ice, while in mild winters (presented in our study as $25 \%$ percentiles) the ice cover occur only on shallow Bays with the rest of the sea remaining ice-free, allowing to conclude that favorable water column for herring maturation and their prey overwintering is remarkably broader in mild winters and narrow during severe winters (Jaagus 2006). Winter air temperature was used as a proxy value to estimate the potential shift in spawning timing due to starvation due to overwintering, and the effect on individual conditions after severe winters. This has been shown to cause considerable overwintering losses and size-selective mortality among young-of-the-year small pelagic species as well as larger predators, like striped bass in northern seas (Martino and Houde, 2012; Anderson and Sharf, 2013). Many studies demonstrate that decreased food availability in winter cause fish to starve and exhaust their energy reserves (Hurst, 2007 and references therein). At the same time, at extremely cold temperatures, acute thermal stress can disrupt osmoregulatory function and become the primary cause of death (McCollum et al., 2003). 
188 To test the effect of winter air temperature on the start of spawning season and changes in age 189 structure, a polynomial regression model was implemented in software PAST (Hammer et al., 190 2001), considering the best-observed pattern of the model fit. First, the linear model was applied, 191 and if a curve model performed significantly better than a simple linear model by taking into 192 account the additional parameters used for smoothing, curve fit regression (polynomial fit) was 193 applied. The maximum number of degrees of freedom was restricted to $3(\mathrm{k}=4)$ to avoid overfitting. 194 The lowest Akaike information criterion (AIC) was obtained with one common trend. The 195 assumptions for normality (Shapiro-Wilk or Kolmogorov-Smirnov), constant variance, and 196 independent residuals were tested before applying polynomial regression. Regression models 197 included: the start of herring spawning season and mean age of spawners (dependent variables), 198 and winter air temperature and calendar week (independent variables).

199 A non-parametric Mann-Kendall trend test was used to detect the presence of long-term trends in 200 annual-scale variables: (a) spawning time and (b) larval onset. The non-parametric Mann-Kendall 201 test was chosen because of the non-linear appearance of most of the trends. Before application of 202 trend test, autocorrelation (AC) was controlled in the response variables.

203

204 Data aggregation

205 Age and condition of fish may affect spawning timing, therefore, we hypothesized that older 206 herrings, having a higher condition factor $(\mathrm{K})$ value, spawn earlier. We hypothesized that despite 207 age, herring $\mathrm{K}$ in spawning season is affected by the previous winter air temperature and the effect 208 differs between young and old herrings. We analyzed herring $\mathrm{K}$ by age: young herring that are 209 first-time spawners (ages 2-3) were compared to old herring that were repeated spawners (ages 4$21010+$ ) to determine if there is a significant difference amongst and between young- and old herring $211 \mathrm{~K}$ after the warmest and the coldest winters.

212 Finally, we tested whether $\mathrm{K}$ affects the herring spawning season. To do this, we split the spawning 213 season into early and late periods (early (prior $\mathrm{cw} 20$ ) and late (after $\mathrm{cw} 21$ )), and compared herring 214 K accordingly.

215 To study the effect of preceding winter air temperature, we aggregated data accordingly: coldest 216 and warmest winters. For such comparison, we used $25 \%$ and $75 \%$ percentiles of winter air 217 temperatures from the years 1999-2015 and selected the years accordingly. 
219 Fulton condition

220 Fulton's condition factor (K, Eq. 1), which assumes that the total weight of a fish is proportional 221 to the cube of its length, was used to measure each individual fish's health (Nash et al., 2006):

$222 \mathrm{~K}=100 * \mathrm{TW}^{\mathrm{T}} \mathrm{TL}^{3}(1)$

223 where TW is total body wet weight in grams and TL is total length in $\mathrm{cm}$; the factor 100 is used to 224 bring $\mathrm{K}$ close to a value of one.

225 To test any differences in median values of $\mathrm{K}$ between young and old individuals and/or after mild 226 and cold winters, one-way analyses of variance (ANOVA) were used. First, data were analyzed 227 for normality of distribution (Wilkinson-Shapiro tests) and equal variance. If the assumptions for 228 Equal Variance were met ( $>00.05)$, a Kruskal-Wallis One Way Analysis of Variance on Ranks 229 Test was run. If the equal variance test failed $(\mathrm{p}<0.05)$ a One Way ANOVA on ranks Tukey test 230 was run, which is more conservative than the Student-Neuman-Keuls Test, i.e., it is less likely to 231 infer that a given difference is statistically different. If the assumptions for normal distribution 232 were not met, Dunn's method in Kruskal-Wallis One Way Analysis of Variance on Ranks test was 233 applied for pairwise comparisons using SigmaStat 12 software (Systat Software, San Jose, CA). 234 For the statistical tests, alpha was set at $<0.05$.

235 The numerical values of the spawning stock biomass of the GoR herring population were taken 236 from publicly accessible stock assessment reports based on catch statistics and regular biological 237 analyses for the determination of age, length, weight, maturity and other relevant parameters 238 (ICES, 2018; Appendix 3).

239

\section{Results}

241 Spawning season

242 The start of spawning season showed interannual variability, occurring between calendar week 15 243 and 20, corresponding with early April and mid-May, respectively (Fig. 2). There was no temporal 244 trend in the start of spawning seasons from 1999-2015 (MannKendall's tau=0.89, p=0.37). 245 Spawning season lasted from six to twelve weeks and its duration was insignificantly affected by 246 the start of spawning season. The first appearance of herring larvae varied between calendar week 24718 and 22, corresponding to early May and early June, respectively. Similar to the start of spawning 248 season, there was no temporal trend in larval herring first appearance in 1999-2015 249 (MannKendall's tau=0.48, $\mathrm{p}=0.63$ ). Earlier larval first appearance corresponded to an earlier start 
250 to spawning season (polynomial regression; $\mathrm{N}=17, \mathrm{AIC}=14.60, \mathrm{~F}=6.886$, adj. $\mathrm{R}^{2}=0.68, \mathrm{p}<0.001$ ).

251 In the years of earlier spawning, the time lag between the start of spawning season and larval first 252 appearance was significantly longer, attributable to the longer duration of embryonal development 253 until hatching as a response to colder temperatures (polynomial regression; $\mathrm{N}=17, \mathrm{AIC}=12.57$, $254 \mathrm{~F}=4.66$, adj. $\left.\mathrm{R}^{2}=0.40, \mathrm{p}<0.05\right)$.

255 The time period when water temperatures of spawning grounds increased to over $17^{\circ} \mathrm{C}$ and resulted 256 in high levels of embryonic mortality varied from cw 21 to 27 . In most years, temperatures became 257 critical for embryonal development in the middle of the spawning season, with an exception in 2582015 when 17 degrees C temperatures were observed several weeks after herring spawning.

259

260 The effect of winter air temperature

261 We did not observe a significant difference in the start of spawning season prior to and after the 262 late 1980s when using winter air temperature and YEAR as covariates (ANCOVA; $\mathrm{F}_{(1 ; 29)}=2.101$, $263 \mathrm{p}>0.05$ ). While winter air temperature contributed significantly in the model (ANCOVA; $\left.264 \mathrm{~F}_{(1 ; 29)}=7.106, \mathrm{p}<0.05\right)$, the YEAR effect remained insignificant (ANCOVA; $\mathrm{F}(1 ; 29)=1.450$, $265 \mathrm{p}>0.05)$.

266 Winter air temperature affected the start of spawning season from 1999-2015 (linear regression; 267 start of spawning $=16.128-(0.227 *$ winter air temperature $), \mathrm{N}=6, \mathrm{AIC}=44.13, \mathrm{~F}=25.123$, adj. $268 \mathrm{R}^{2}=0.83, \mathrm{p}<0.001$, Fig. 3). The spawning season following cold winters began in mid-May (cw 269 20), which is six weeks later than the start of spawning season following the warmest winter.

270 Herring spawning stock biomass and the number of old herrings (abundance of age group 4+) 271 varied markedly in an annual scale. The lowest spawning stock biomass was observed in 2006 and 272 the highest in 2014 (69.9 and $119.6 \times 10^{3}$ tonnes, respectively) from 1999-2015 (Fig. 4). Number 273 of old herrings varied between 13.0 and $27.3 \times 10^{6}$ individuals. Neither GoR herring spawning 274 stock biomass nor the number of old herrings from 1999-2015 significantly explained the start or 275 duration of herring spawning season (polynomial regression; $\mathrm{N}=17, \mathrm{p}>0.05$ ).

276

277 Herring age structure during the spawning season

278 The changes in the mean age of herring displayed a seasonal pattern with the oldest, repeat 279 spawners dominating at the start of spawning season, and young, first time spawning individuals 280 prevailing towards the end of the season (polynomial regression; mean age $=2.402+(0.214$ 
28 282 Fig. 5).

283 The correlation between the progression of herring average age and calendar week during 284 spawning period by each year from 1999-2015 varied in a broad scale (Pearson correlation 285 coefficient: $\mathrm{R}=-0.04$ to -0.84$)$. The strength of correlation between the average age of spawner 286 28 288 289 290 291

292

293 294 295

296

297

298

299

300

301

302

303

304

305

306

307

308

309

310

311

*calendar week $)-\left(0.00698 *\right.$ calendar week $\left.{ }^{2}\right) \mathrm{N}=11, \mathrm{AIC}=6.02, \mathrm{~F}=146.89$, adj. $\mathrm{R}^{2}=0.95, \mathrm{p}<0.001$,

and $\mathrm{cw}$ was determined by preceding winter air temperature (polynomial regression; $\mathrm{N}=16$, $\mathrm{AIC}=394.55, \mathrm{~F}=6.86$, adj. $\mathrm{R}^{2}=0.36, \mathrm{P}<0.05$ ). The strength of correlation improved remarkably in the years with the coldest winters and it was relatively moderate in years with warm winters, indicating the importance of preceding environmental conditions in shaping changes in herring age structure during spawning.

Variation in herring individual condition factor $(\mathrm{K})$

The largest difference in condition factor occurred between young herring after cold winters and old herring after warm winters (Kruskal-Walls One-way ANOVA; $\left.\mathrm{F}_{1 ; 46}\right)=9.98, \mathrm{p}<0.01$, Fig. 6). Also, young herring were in better condition after warm winters than after cold winters (KruskalWallis One-way ANOVA; $F(1 ; 46)=5.69, \mathrm{p}<0.05)$, while old herring had similar $\mathrm{K}$ despite winter air temperature (Kruskal-Wallis One-way ANOVA; $\left.\mathrm{F}_{1 ; 48}\right)=1.38, \mathrm{p}>0.05$ ).

Despite the timing of the spawning season, within age groups the condition was similar (KruskalWallis One-way ANOVA; $>0.05$; Fig. 7). Only old herring spawning in late in the season had a higher condition, compared to early spawning young herring (Tukey Test One-way ANOVA; $\mathrm{Q}=3.43, \mathrm{p}<0.01)$.

\section{Discussion}

In the present study, we aimed to investigate GoR spring herring spawning seasonality and changes in age composition throughout the spawning season from 1999-2015, as well as to analyze the effect of preceding winter air temperature and $\mathrm{K}$ on spawning seasonality. We found that preceding winter air temperature influenced herring spawning and larval first appearance. The spawning season began up to six weeks earlier after the mildest winter compared to the coldest winters. There were no significant differences in the start of spawning season before and after the climatic regime shift beginning in the late 1980s in the Baltic Sea. It seems that several observed warmer winters in recent period contribute to remarkably earlier herring spawning and in former period, 
312 despite of several very cold winters, herring spawning was not remarkably affected. On the other 313 words, warmer than average conditions in winter, seems to have significant effect on herring earlier 314 spawning, while colder than average winters seems do not affect start of herring spawning. The K 315 amongst young or old individuals was similar despite spawning time, while the winter air 316 temperature had a significant effect by age group. Young herring displayed poorer K compared to 317 old herring after cold winters, indicating that first-time spawners are more sensitive and influenced 318 by preceding winter conditions.

319 Winter air temperature preceding to herring spawning migration affected the start of spawning 320 season by shifting it up to six weeks earlier after the mildest winters compared to the coldest

321

322 323

324 winters. The mechanism governing such a pattern might be that of the shallow gulf, where herring and its prey's overwintering habitat is situated in the areas where the longest temporal extent of ice cover occurs. Winter air temperature determines water thermal regimes in winter and controls the success of herring reproduction by mainly limiting habitat conditions of gulf herring in winter (Ojaveer 1988). The area and distribution of the thermophilic organism are affected, especially of those that inhabit the NE region of the Baltic Sea. We chose winter air temperature because cold winters have been observed to limit the volume of water in shallow gulfs in which wintering, feeding and preparation for reproduction (maturation) of herring occurs (Ojaveer and Kalejs 2010). In the Estonian coast winter severity is variable, and in severe winters (presented in our study as the $75 \%$ percentile) the whole sea surface is covered by ice, while in mild winters (presented in our study as the $25 \%$ percentile) the ice cover exists only on shallow bays, and the rest of the sea is ice-free (Jaagus 2006). This allows us to conclude that the favorable water column conditions for overwintering herring and their prey is markedly wider in mild winters and limited in severe winters, reducing the probability for good overwintering conditions for faster maturation. Such a high variability allows one to assume that winter air temperature should be a sensitive indicator of extensively variable local climate conditions.

Changes in spawning location and timing could result in early life stage dispersal to inadequate habitats for the continuation of the life cycle (Secor, 2015). Alternatively, consistent spawning locations and timing could interact with changing thermal environments and result in larvae not arriving at suitable habitats for the continuation of the life cycle (Shoji et al., 2011). In the present study, we observed considerable inter-annual variation without a long-term pattern at the start of spawning season. The start of spawning season varied by six weeks and was strongly linked to the 
343 preceding winter air temperature, with more severe winters resulting in delayed spawning and 344 hatching of larvae. Delayed hatching of fish larvae result temporal mismatch with suitable prey, 345 causing elevated mortality rates amongst fish recruitment cohort (Houde, 1989; Arula et al., 346 2014a,b, 2016). Such changes in prey and predator overlap might affect the survival of larvae 347 (Llopiz et al., 2014), and a shift in spawning may result in a change in the productivity of spawning 348 stock biomass. Genner et al. (2010) found a correlation between changes in the timing of larval 349 occurrence of several spring spawning fish species and temperature in the English Channel: 350 spawning occurred earlier with increasing temperatures for spring spawners. Despite significant 351 effects of winter air temperature on herring spawning in the NE of the GoR, we did not observe a 352 significant trend from 1999-2015 or significant difference in the start of spawning before and after 353 the 1990s, indicating high plasticity of gulf herring spawning.

354 Changes in adult and early life stage behavior can affect connectivity, recruitment, and population 355 biomass (Secor, 2015). Adults of many species make large migrations to specific spawning 356 grounds during the same season year after year, presumably targeting the most favorable spawning 357 and nursery grounds to increase the chances of larval survival (Ciannelli et al., 2015; Secor, 2015). Therefore, it is believed that population biomass variability could be a response of spawning 359 behavior to ensure success of survival in early life stages (Hjort, 1914; Houde, 2008; Peck et al., 2012). The first appearance of fish larvae is determined by the timing of spawning, as shown in 361 the present study. Lambert $(1987,1990)$ found that spawning duration of herring is dependent on the number of spawning waves, which is dependent on the number of year classes present in 363 spawning stock. We did not find either GoR herring spawning stock biomass or the abundance of 364 old repeat spawners to correlate with the start of spawning nor the duration of spawning season. 365 In contrast, for Icelandic summer-spawning herring, it was shown that spawning occurs on average seven days later when spawning stock biomass is greater than the long-term average, which might be the result of higher food competition and therefore slower ovary growth (Óskarsson and Taggart, 2009). It could be expected that if spawning season starts later, it also ends later than in conditions when earlier spawning occurs. However, there was no such consistent pattern in our study, indicating that Baltic herring spawning duration is mainly modified by the age structure of spawners -- temperatures during the spawning season and a later start to spawning in the season will not have any effect on the duration or ending date. Also, regardless of the start of spawning 
373 season, herring embryos had similar chances of exposure to unfavorable conditions in terms of 374 water temperature exceeding their thermal tolerance (Ojaveer, 1981).

375 Gonad maturation is thermally regulated and is proposed to drive the spawning and larval 376 appearance of marine fish (Lange and Greve, 1997). Several studies have demonstrated how 377 gonadal maturation rates improve in warmer environments. For example, in Lake Geneva, the 378 precise time of roach (Rutilus rutilus) spawning during late spring is related to the cumulative sum 379 of degree-days since the previous October when gonad development begins (Gillet and Quetin, 380 2006). Former studies in the Baltic Sea demonstrated a climate triggered regime shift, which 381 resulted in reorganization in the food web as well as warmer winters since the late 1980s 382 (Mollmann et al., 2008; Arula et al., 2014). Warmer winters favored survival of young herring that 383 were recruited to the herring population and increased the relative number of first-time spawners 384 in the population (Ojaveer et al., 2011) and accelerated the maturation cycle of young and old 385 herring. Our results show that the differences in $\mathrm{K}$ between young and old herring were the greatest 386 after severe winters. Young herring displayed significantly higher $\mathrm{K}$ after mild winters compared 387 to severe winters, while winter air temperature did not affect $\mathrm{K}$ of repeated spawning older 388 herrings. These results might also explain why the timing of spawning is age-dependent and does 389 not depend on spawning stock size. Our findings, related to fish $\mathrm{K}$ after exposure to acute cold stress in severe winters, support conclusions implicating nutritional deficiency as the proximate 391 cause of decreased $\mathrm{K}$, rather than density-dependency before winter since herring spawning stock 392 biomass did not correlate with spawning time or duration. Exposure to winter conditions, both 393 mild and severe, resulted in a decrease in $\mathrm{K}$ during the spawning season, most likely attributable 394 to decreased feeding rates at cold temperatures. The mechanism of reduced spawning appears to 395 be low temperatures that are unfavorable for herring feeding (longer fasting periods because 396 herring do not feed at temperatures below 2 degrees $\mathrm{C}$ ), and there is a reduced rate in accumulation 397 of energy prior to the reproduction and development of its gametes (Ojaveer, 1988).

398 Winter mortality is size-selective, with lasting influences on cohort demographics (Martino and 399 Houde, 2012). Small fish are generally more vulnerable because of higher relative energetic 400 demands coupled with a reduced capacity for lipid storage (Post and Evans, 1989). On the other 401 hand, in severe winters, an entire cohort is expected to have high mortality rates, regardless of 402 body size (McCollum et al., 2003; Michaletz, 2010). Therefore, it is plausible that density403 dependent processes will have a greater impact on overwinter survival during mild or moderate 
404 winters. While we did not measure the density-dependency in terms of growth rates and feeding 405 conditions of herring before winter, we observed that young herring had the poorest $\mathrm{K}$ after cold 406 winters, implying that despite feeding conditions prior to winter, winter air temperature determines 407 spawner $\mathrm{K}$ and has a more pronounced effect for younger individuals. Since young herring in our 408 study denote first-time spawners that began maturation most recently, these results are in contrast 409 to McCollum et al. (2003), which shows that severe winters will have equal effect for an entire 410 population and across body sizes (as a proxy of age). Age of fish is an important and main 411 determinant, regulating the condition and timing of spawning, and can likely reflect overwintering 412 mortality rates that vary among ages.

413 It has been demonstrated that the annual maturation process of herring is size-specific rather than 414 age-specific (Lambert, 1987; Ware and Tanasichuk, 1989) and herring tend to school according to 415 size (see references in Lambert (1987)) rather than age. These aggregations are more exaggerated 416 during spawning due to additional behavioral cues associated with the actual spawning act. It is 417 possible that herring of a large year class tend to "entrain" individuals of adjacent year classes. 418 Thus, fish above and below the modal length of the dominant year class would tend to aggregate. 419 This effect is possibly diminished below a certain population density. We show that, despite 420 previous evaluations, Baltic herring spawning shows a certain temporal pattern in terms of 421 consecutive age groups that migrate to spawn. We found that old, repeat spawners dominate at the 422 beginning of spawning season while young, first time spawning individuals followed older herring 423 cohorts and spawn later in the season. Some studies show that young, first time spawning herrings 424 in the North Sea arrive on spawning grounds before repeat spawners (Lambert, 1990). However, 425 we did not observe such a pattern in the GoR herring. It has been suggested that exceptions are 426 caused by different age groups inhabiting separate geographical regions prior to spawning 427 migration (Lambert, 1987). Since the distinct Baltic herring populations (GoR and Central Baltic 428 Herring), have different thermal preferences but the same spawning grounds in the NE GoR, mild 429 winter air temperature results in a more even spawning period, but forces distinct populations with 430 different adaptations to utilize the same spawning season after the coldest winters. The potential 431 effect of the population structure of spawning schools of herring on the timing of spawning, 432 structure, and the survival of the annual larval component in the area deserves further investigation. 433

434 Conclusions 
435

436

437

438

439

440

441

442

443

444

445

446

447

448

449

450

451

452

453

454

455

456

457

458

459

460

461

462

463

464

465

466

467

468

1. The start-date of the herring spawning season varied by months, starting earlier after mild winters, and can be predicted accurately from preceding winter air temperatures.

2. As the spawning season progressed, successively younger individuals replaced older spawners; this pattern varied interannually in response to preceding winter air temperature.

3. Climate-driven regime shifts in the Baltic Sea have resulted in milder winters, but the start-date of the herring spawning season has not changed, indicating non-linear response of Baltic herring spawning to climate warming.

\section{Acknowledgements}

The authors are grateful to the editors, two anonymous reviewers and Edward D. Houde for sharing insight in earlier versions of the manuscript.

\section{References}

Anderson, D.A. and Scharf, F.S. 2013. The effect of variable winter severity on size-dependent overwinter mortality caused by acute thermal stress in juvenile red drum (Sciaenops ocellatus). ICES J. Mar. Sci. doi:10.1093/icesjms/fst041

Arula, T., Kotta, J., Lankov, A., Simm, M., Põlme, S. 2012. Diet composition and feeding activity of larval spring-spawning herring: Importance of environmental variability. Journal of Sea Research. 68: 33-40.

Arula, T., Gröger P.J., Ojaveer H., Simm M. 2014a. Shifts in the spring herring (Clupea harengus membras) larvae and related environment in the Eastern Baltic Sea over the past 50 years. PLoS One 9(3): e91304.

Arula, T., Ojaveer H., Klais, R. 2014b. Impact of extreme climate and bioinvasion on the temporal coupling of spring herring (Clupea harengus $m$.) larvae and their prey. Marine Environmental Research. DOI: 10.1016/j.marenvres.2014.05.001

Arula, T., Laur K., Simm M., Ojaveer, H. 2015. Dual impact of temperature on growth and mortality of marine fish larvae in a shallow estuarine habitat. Estuarine, Coastal and Shelf Science. 167: 326-335.

Arula, T., Raid, T., Simm, M., Ojaveer, H. 2016. Temperature-driven changes in early life-history stages influence the Gulf of Riga spring spawning herring (Clupea harengus m.) recruitment abundance. Hydrobiologia. 767: 125-135. 
469 Brunel, T. and Piet, G. J. 2013. Is age structure a relevant criterion for the health of fish stocks? 470 ICES Journal of Marine Science. 70: 270-283.

471 Ciannelli, L., Bailey, K., Olsen, E.M. 2014. Evolutionary and ecological constraints of fish 472 spawning habitats. ICES Journal of Marine Science. 72: 285-296.

473 Dragesund, O. 1970. Factors influencing year-class strength of Norwegian spring spawning 474 herring (Clupea harengus Linne). FiskDir. Ski. Ser. HavUnders 15: 381-150.

475 Geffen, A.J. 2009. Advances in herring biology: from simple to complex, coping with plasticity 476 and adaptability. ICES J. Mar. Sci. 66: 1688-1695

477 Genner, M.J., Halliday, N.C., Simpson, S.D., Southward, A.J., Hawkins, S.J., Sims, D.W., 2010.

478 Temperature-driven phenological changes within a marine larval fish assemblage. J. Plankton Res. 479 32: 699-708.

480 Gillet, C. and Quetin, P. 2006. Effect of temperature changes on the reproductive cycle of roach 481 in Lake Geneva from 1983 to 2001. J. Fish Biol. 69: 518-534.

482 Hammer, Ø., Harper, D.A.T., Ryan, P.D. 2001. PAST: Paleontological statistics software package 483 for education and data analysis. Palaeontologia Electronica 4(1): 9pp. http://palaeo484 electronica.org/2001 1/past/issue1 01.htm

485 Hjort, J. 1914. Fluctuations in the great fisheries of Northern Europe viewed in the light of 486 biological research. Rapp. Proc. Verb. Reun. Cons. Int. Explor. Mer. 20: 1-228.

487 Houde, E.D. 1989. Comparative growth, mortality and energetics of marine fish larvae: 488 temperature and implied latitudinal effects. Fish. Bull., U. S. 87:471 495.

489 Houde, E.D. 2008. Emerging from Hjort's shadow. Journal of Northwest Atlantic Fishery Science. 490 41: 53-70.

491 Hurst, T.P. 2007. Causes and consequences of winter mortality in fishes. Journal of Fish Biology. 492 71:315-345

493 ICES 2011. Report of the workshop on sexual maturity staging of herring and sprat (WKMSHS), 494 20-23 June 2011, Charlottenlund, Denmark. ICES CM 2011/ACOM: 46.143 495 pp.http:/www.ices.dk/sites/pub/Publication\%20Reports/Expert\%20Group\%20Report/acom/201 496 1/WKMSHS/ WKMSHS\%20Report\%202011.pdf.

497 ICES 2018. Report of the Baltic Fisheries Assessment Working Group (WGBFAS): 6-13 April 498 2018, Copenhagen, Denmark. International Council for the Exploration of the Sea. 
499 Jaagus, J. 2006. Trends in sea ice conditions in the Baltic Sea near the Estonian coast during the 500 period 1949/1950-2003/2004 and their relationships to large-scale atmospheric circulation. Boreal 501 Env. Res. 11:169-183

502 Kjesbu, O.S. 1994. Time of start of spawning in Atlantic cod (Gadus morhua) females in relation 503 to vitellogenic oocyte diameter, temperature, fish length and condition. Journal of Fish. Biol. 45: 504 719-735.

505 Lambert, T.C and Ware, D.M. 1984. Reproductive strategies of demersal and pelagic spawning 506 fish. Can. J. Fish. Aquat. Sci. 41: 1565-1569.

507 Lambert, T.C. 1987. Duration and intensity of spawning in herring (Clupea harengus) as related 508 to the age structure of the mature population. Mar. Ecol. Prog. Ser., 39: 209-220.

509 Lambert, T.C. and Messieh. S. N. 1989. The spawning dynamics of Gulf of St. Lawrence herring. 510 Can. J. Fish. Aquat. Sci. 46(10): 2085-2094.

511 Lambert, T.C. 1990. The effect of population structure on recruitment in herring. ICES Journal of 512 Marine Science. 47: 249-255.

513 Lange, U. and Greve, W. 1997. Does temperature influence the spawning time, recruitment and 514 distribution of flatfish via its influence on the rate of gonadal maturation? Deutsche 515 Hydrographische Zeitschrift. 49: 251-263.

516 Llopiz, J.K., Cowen, M.J., Hauff, R., Ji, P.L., Munday, B.A., Muhling, M., Peck, M.A.,

517 Richardson, E.D., Sogard, S., Sponaugle, S. 2014. Early life history and fisheries oceanography:

518 New questions in a changing world. Oceanography. 27(4): 26-41,

519 http://dx.doi.org/10.5670/oceanog.2014.84.

520 Margonski, P., Hansson, S., Tomczak, M. T. and Grzebielec, R. 2010. Climate influence on Baltic 521 cod, sprat, and herring stock-recruitment relationships. Progress in Oceanography. 87: 277-288.

522 McCollum, A.B, Bunnell, D.B, Stein, R.A. 2003. Cold, northern winters: the importance of 523 temperature to overwinter mortality of age-0 white crappies. Trans Am Fish Soc. 132: 977-87.

524 Michaletz, P. H. 2010. Overwinter survival of age-0 gizzard shad in Missouri reservoirs spanning 525 a productivity gradient: roles of body size and winter severity. Transactions of the American 526 Fisheries Society. 139: 241-256

527 Mollmann, C., Muller-Karulis, B., Kornilovs, G., and St John, M.A. 2008. Effects of climate and 528 overfishing on zooplankton dynamics and ecosystem structure: regime shifts, trophic cascade, and 529 feeback loops in a simple ecosystem. ICES Journal of Marine Science. 65: 302-310. 
530 Nash, R.D.M., Valencia, A.H., Geffen, A.J. 2006. The origin of Fulton's condition factor - setting 531 the record straight. Fisheries. 31(5): 236-238.

532 Ojaveer, E. 1981. Influence of temperature, salinity, and reproductive mixing of Baltic herring 533 groups on its embryonal development. Rapports et Proces-Verbaux des Reunions Conseil 534 International pour l'Exploration de la Mer, 178: 409-415.

535 Ojaveer, E.A. 1988. Baltiskie seldi. Agropromizdat, Moscow. 205 pp. Doctoral thesis. (in 536 Russian).

537 Ojaveer, E., Pihu, E., Saat, T. 2003. Fishes of Estonia. Estonian Academy Publishers.

538 Ojaveer, E., Raid, T., Suursaar, Ü. 2004. On the Assessment and Management of Local Herring 539 Stocks in the Baltic. In Management of Shared Fish Stocks, pp. 240-250. Ed. by A. I. L. Payne, 540 C.M. O’Brien, S.I. Rogers. Blackwell Publishing Ltd.

541 Ojaveer, E., Arula, T., Lankov, A., Shpilev, H. 2007. Abundance dynamics of herring larvae in 542 the NE of Gulf of Riga (Baltic Sea) in 1947 - 2005 and its relation to stock recruitment. 2007 ICES 543 ASC Handbook: ICES Annual Science Conference 2007, 17 - 21 Sept. 2007, Helsinki, 544 Finland. Denmark: ICES, 114.

545 Ojaveer E. and Kalejs M. 2010. Ecology and long-term forecasting of sprat (Sprattus sprattus 546 balticus) stock in the Baltic Sea: a review. Rev Fish Biol Fish. 20:203-217

547 Ojaveer, E., Arula, T., Lankov, A., Shpilev, H. 2011. Impact of environmental deviations on the 548 larval and year-class abundances in the spring spawning herring (Clupea harengus membras L.) 549 of the Gulf of Riga (Baltic Sea) in 1947-2004. Fisheries Research. 107: 159-168.

550 Peck M.A., Kanstinger P., Holste L., Martin M. 2012. Thermal windows supporting survival of 551 the earliest life stages of Baltic herring (Clupea harengus). ICES J. Mar. Sci. 69: 529-536. 552 Planque, B., Fromentin, J.-M., Cury, P., Drinkwater, K. F., Jennings, S., Perry, R. I., Kifani, S. 553 2010. How does fishing alter marine populations and ecosystems sensitivity to climate? Journal of 554 Marine Systems. 79: 403-417.

555 Post, J.R. and Evans, D.O. 1989. Size-dependent overwinter mortality of young-of-the-year yellow 556 perch (Perca flavescens): laboratory, in situ enclosure, and field experiments. Canadian Journal of 557 Fisheries and Aquatic Sciences. 46: 1958-1968.

558 Raid, T. 1985. The reproduction areas and ecology of Baltic herring in the early stages of 559 development in the Soviet zone of the Gulf of Finland. Finnish Fish. Res. 6: 20-34. 
560 Raid, T., Kornilovs, G., Lankov, A., Nisumaa, A-M., Shpilev, H., Järvik, A. 2010. Recruitment 561 dynamics of the Gulf of Riga herring stock: density-dependent and environmental effects. ICES 562 Journal of Marine Science. 67: 1914 - 1920.

563 Raid, T.; Arula, T.; Kaljuste, O.; Sepp, E.; Järv, L.; Hallang, A.; Shpilev, H.; Lankov, A. 2015. 564 Dynamics of the commercial fishery in the Baltic Sea: what are the driving forces? Towards Green 565 Marine Technology and Transport: Proceeding of the 16th International Congress of the 566 International Maritime Assotiation of the Mediterranean (IMAM 2015), Pula, Croatia, 21-24 567 September. Ed. C. Guedes Soares; R. Dejhalla; D. Pavletic. Taylor \& Francis, 897-906.

568 Rannak. 1971. On the recruitment to the stock of the spring herring in the North-eastern Baltic. 569 Rapp. P.-v. Réun. Cons. int. Explor. Mer. 160 : 76-82.

570 Secor, D. H. 2000. Spawning in the nick of time? Effect of adult demographics on spawning 571 behaviour and recruitment in Chesapeake Bay striped bass. ICES Journal of Marine Science. 57: $572 \quad 403-411$.

573 Secor, D.H. 2015. Migration Ecology of Marine Fishes. Johns Hopkins University Press, 574 Baltimore, MD. 304 pp.

575 Shoji, J., Toshito, S., Mizuno, K., Kamimura, Y., Hori, M., Hirakawa, K. 2011. Possible effects of 576 global warming on fish recruitment: shifts in spawning season and latitudinal distribution can alter 577 growth of fish early life stages through changes in daylength. ICES Journal of Marine Science. 68: $578 \quad 1165-1169$.

579 Sims, D.W., Wearmouth, V.J., Genner, M.J., Southward, A.J., Hawkins, S.J. 2004. 580 Low-temperature-driven early spawning migration of a temperate marine fish. Journal of Animal 581 Ecology. 73: 333-341.

582 Sissener, E.H., and Bjørndal, T. 2005. Climate change and the migratory pattern for Norwegian 583 spring-spawning herring —implications for management. Marine Policy. 29: 299-309.

584 Slotte, A., Johannessen, A., Kjesbu, O. S. 2000. Effects of fish size on spawning time in Norwegian 585 spring-spawning herring. Journal of Fish Biology. 56: 295-310.

586 Ware, D.M. and Tanasichuk, R. 1989. Biological basis of maturation and spawning waves in 587 Pacific herring (Clupea harengus pallasi). Can. J. Fish. Aquat. Sci. 46(10): 1776-1784. 


\section{Figure 1}

Rectangles showing the area of herring commercial catches and data sampling.

Rectangles showing the area of herring commercial catches and data sampling to characterize herring spawning. Stars denote stations of larval herring collection and water temperature measurements. 


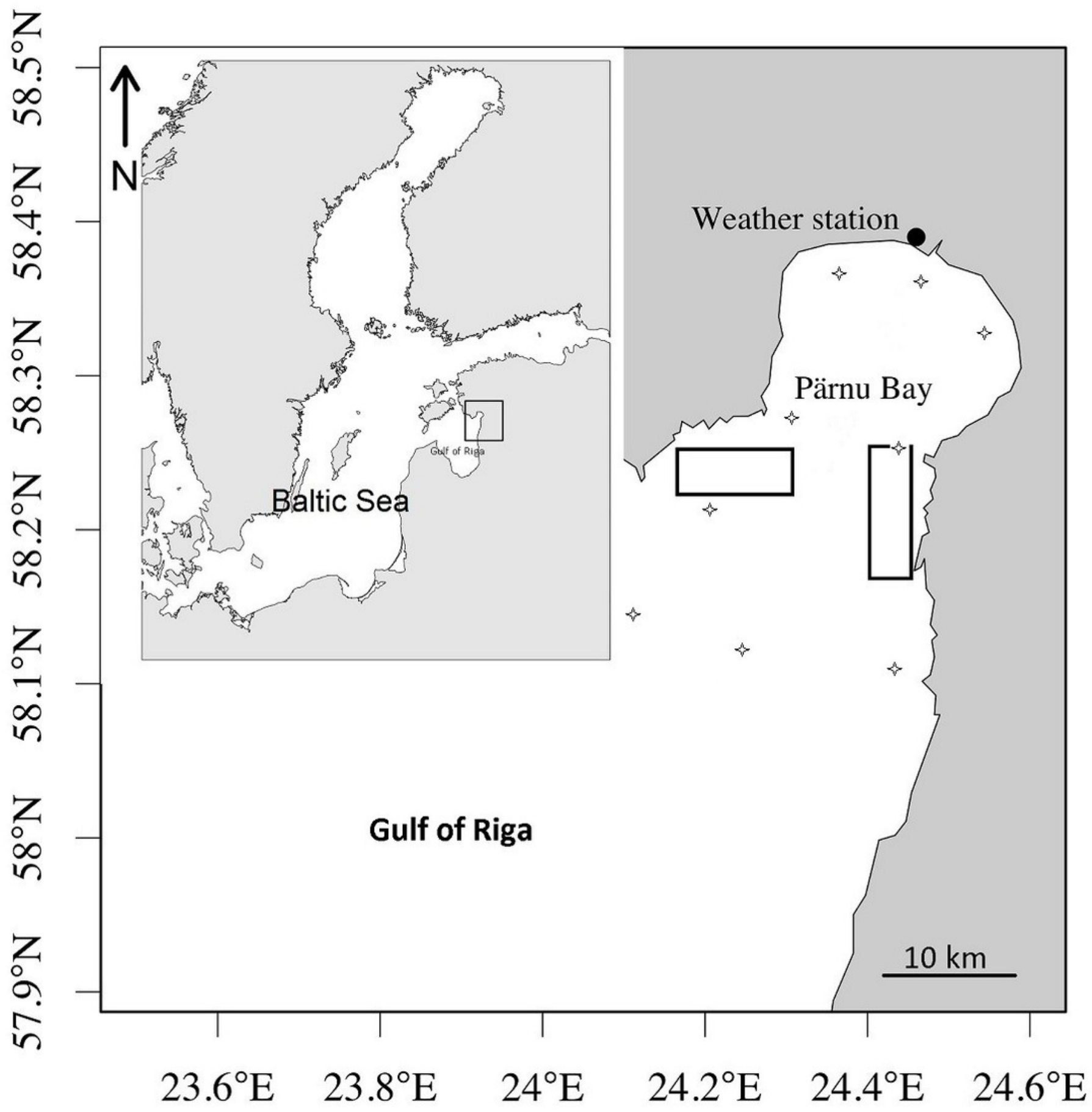


Figure 2

Gulf of Riga herring spawning (black bar) and larvae (grey bar) distribution seasons.

Gulf of Riga herring spawning (black bar) and larvae (grey bar) distribution seasons in 1999-2015. Red dots denote the time when water temperatures exceed $17^{\square} \mathrm{C}$, which is considered critical for normal embryonic development (Ojaveer 1981). 


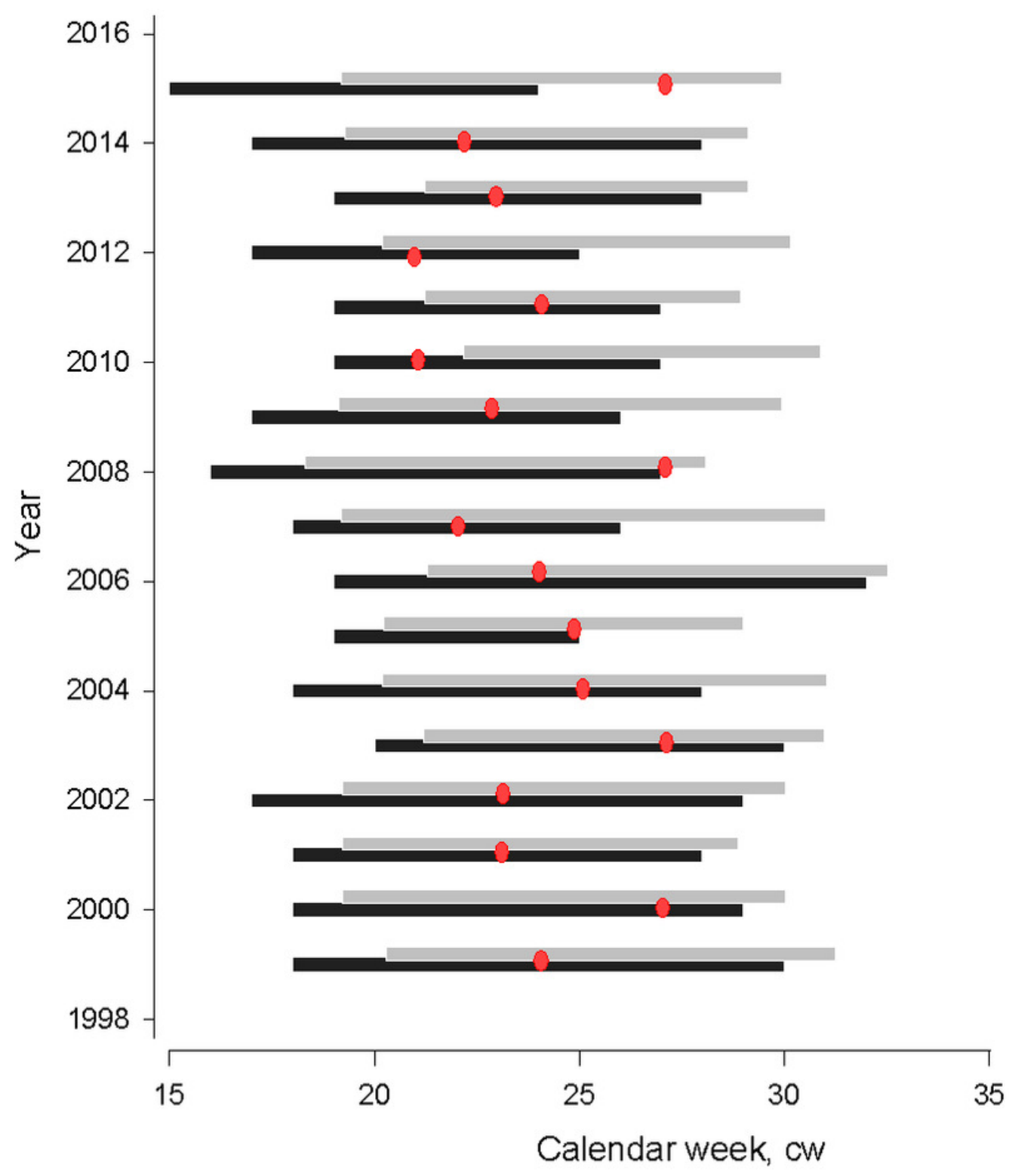


Figure 3

The linear regression between the start of herring spawning season and sum of mean monthly winter air temperature.

The linear regression between the start of herring spawning season and sum of mean monthly winter air temperature in 1999-2015. Error bars $=1$ s.e. 


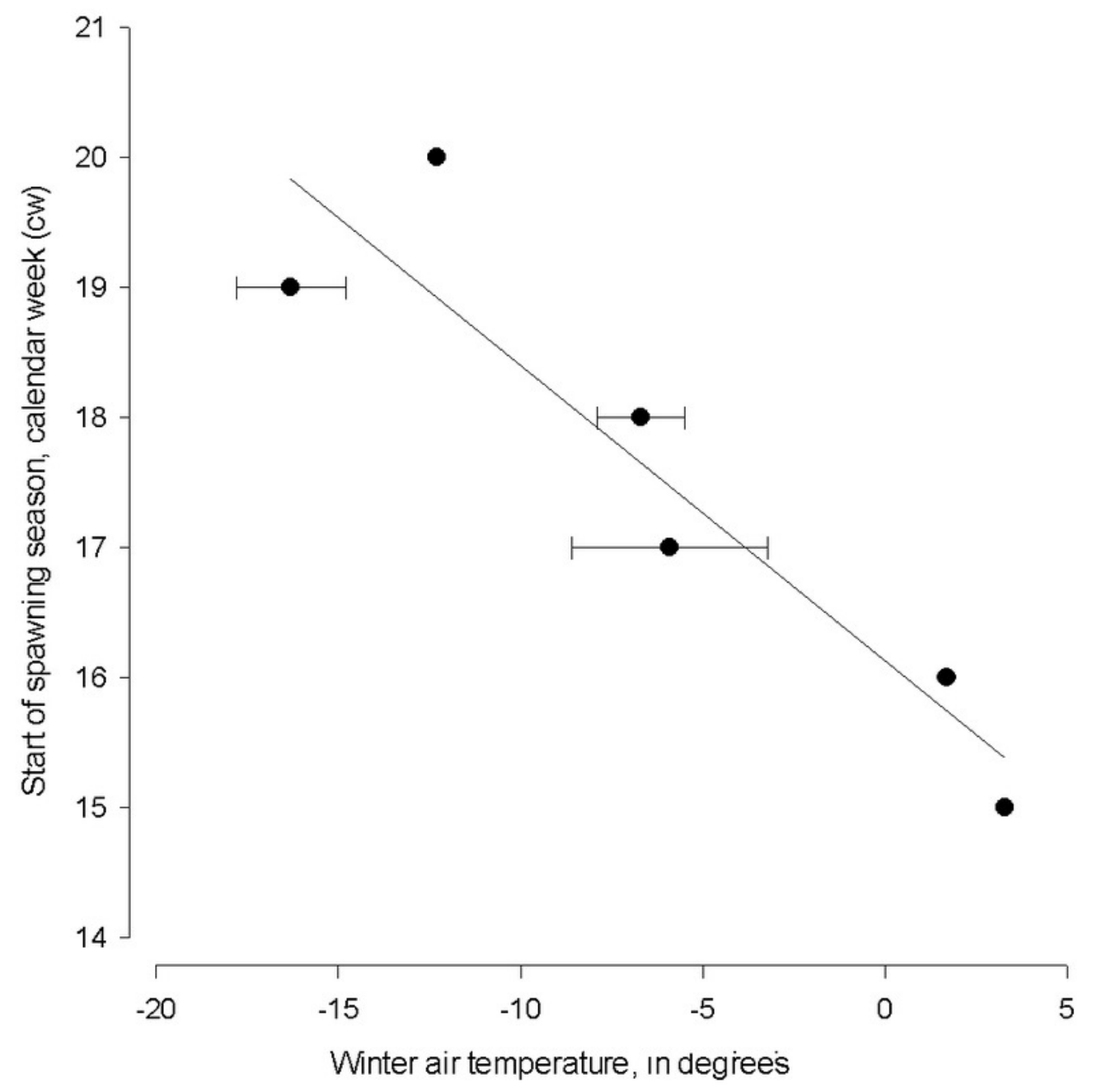




\section{Figure 4}

Dynamics of spawner biomass and abundance of age 4-10+

The temporal dynamics of the Gulf of Riga herring spawning stock biomass, Spawning stock biomass (a) and age 4-10+ individuals abundance (b) in spawning stock in 1999-2015 (ICES, 2018). 

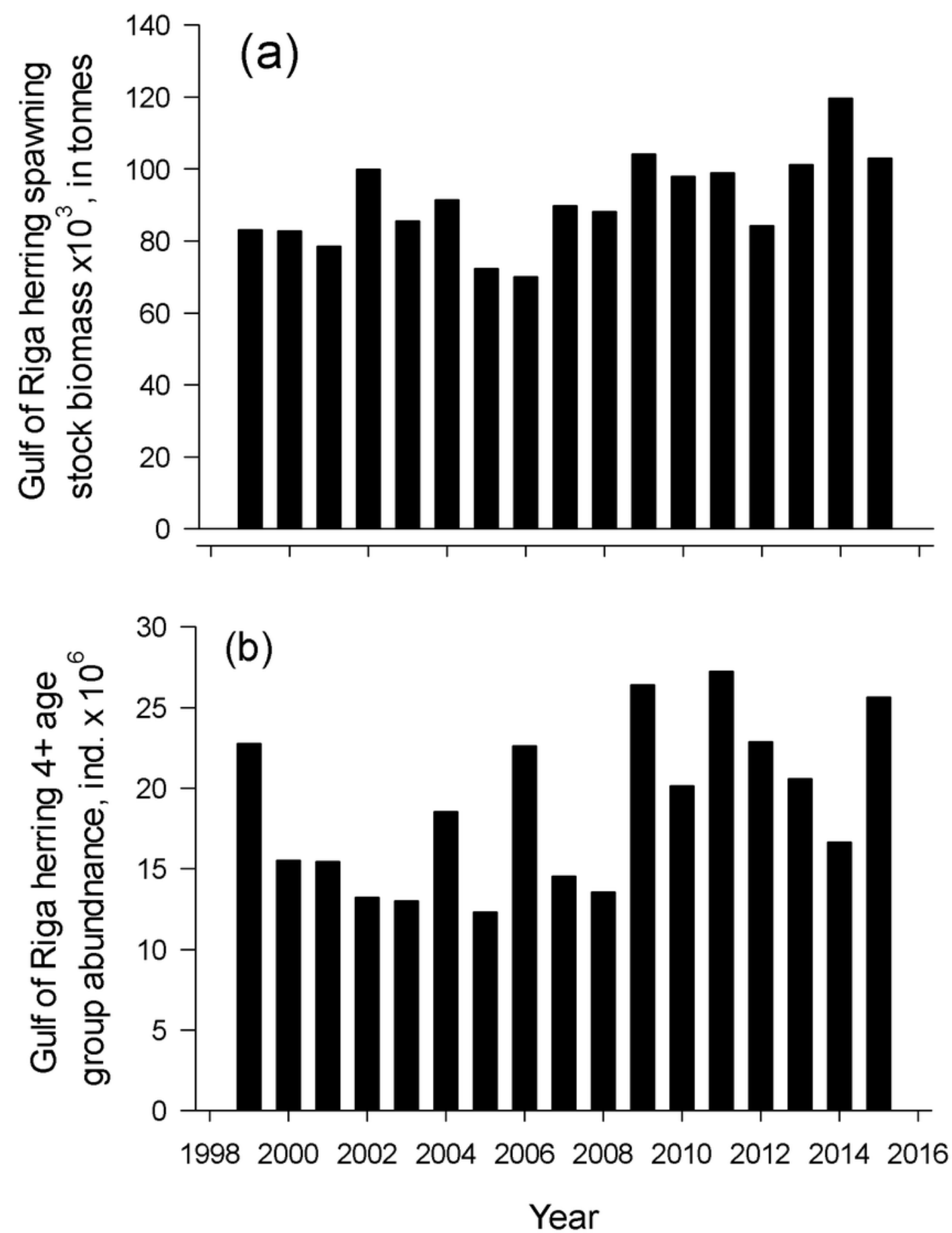


\section{Figure 5}

The temporal dynamics of Baltic spring spawning herring mean age during the spawning season.

The temporal dynamics of Baltic spring spawning herring mean age during the spawning season. Each data point in particular calendar week (cw) denote average age for 1999-2015. Error bars $=1$ s.e. 


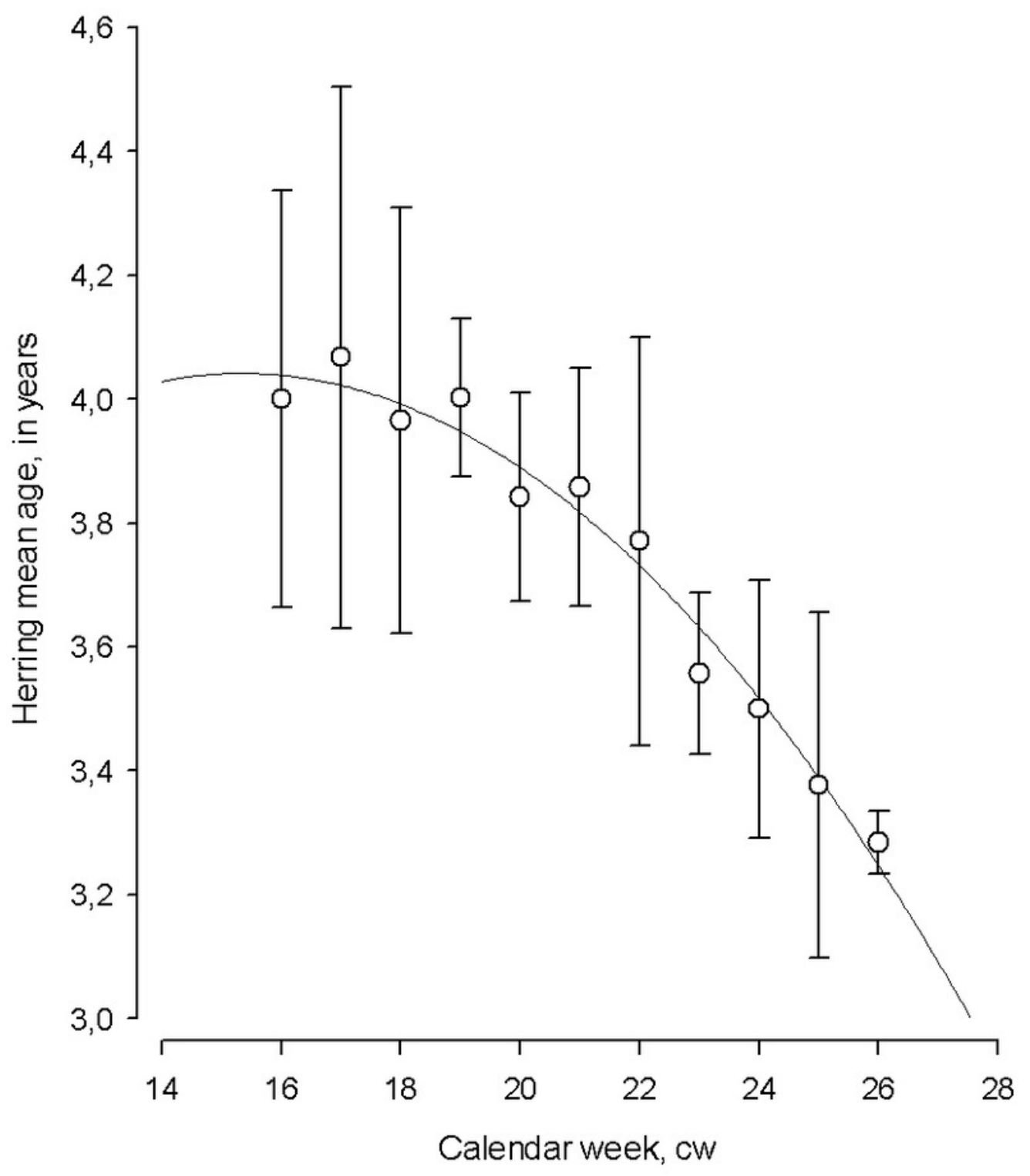




\section{Figure 6}

Box plots of the Fulton condition factor ( $\mathrm{K}$ ) of young (2-3 year) and old (4-10+ year) herring after cold and warm winter.

Figure 6. Box plots of the Fulton condition factor ( $K$ ) of young (2-3 year) and old (4-10+ year) herring after cold and warm winter ( $25 \%$ and $75 \%$ percentiles of winter air temperatures over the years in 1999-2015). Vertical boxes denote quartiles, the line inside the box median, whiskers 10th and 90th percentiles, and dots show extreme values. Different letters indicate $p<0.05$. 


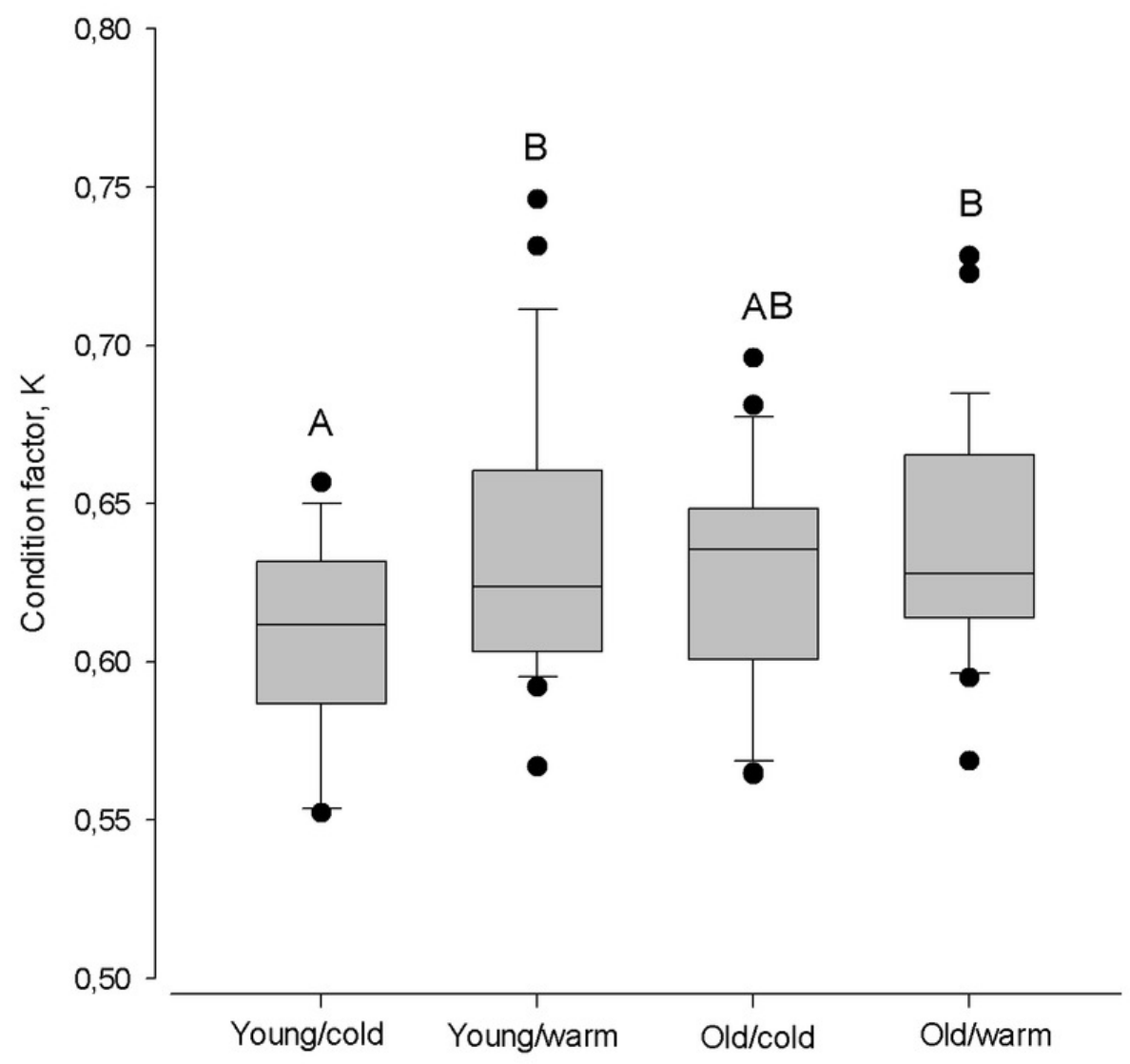




\section{Figure 7}

Box plots of the Fulton condition factor (K) of young (2-3 year) and old herring (4-10+ year) in early (prior cw 20) and late (after cw 21) spawning season.

Box plots of the Fulton condition factor $(\mathrm{K})$ of young (2-3 year) and old (4-10+ year) herring after cold and warm winter (25\% and $75 \%$ percentiles of winter air temperatures over the years in 1999-2015). Vertical boxes denote quartiles, the line inside the box median, whiskers 10th and 90th percentiles, and dots show extreme values. Different letters indicate $p<0.05$. 


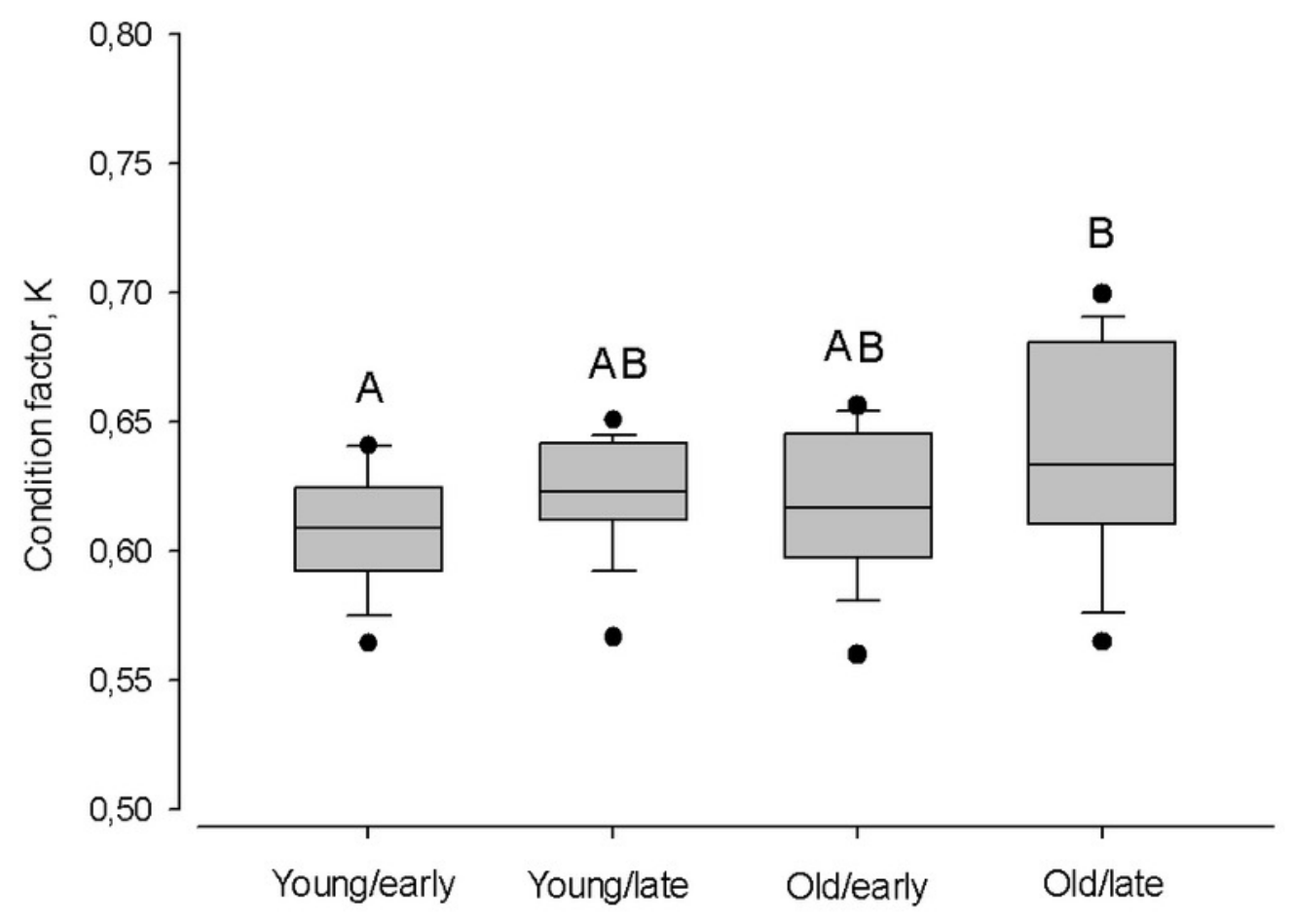




\section{Table $\mathbf{1}$ (on next page)}

Table 1. Number of matured individuals collected from trap-net catches and analyzed in present study. 
2 Table 1 . Number of matured individuals $(\mathrm{N}=12031)$ collected from trap-net catches and analyzed in present study.

\begin{tabular}{c|cccccccccccccccccccccccccccc} 
Year & 99 & 00 & 01 & 02 & 03 & 04 & 05 & 06 & 07 & 08 & 09 & 10 & 11 & 12 & 13 & 14 & 15 \\
\hline $\begin{array}{c}\text { Number of individuals } \\
\text { analysed }\end{array}$ & 794 & 777 & 642 & 706 & 587 & 533 & 439 & 585 & 654 & 617 & 669 & 998 & 647 & 862 & 994 & 741 & 786
\end{tabular}

3 